\title{
Anti-inflammatory screening of plant species from the Colombian Caribbean Coast
}

\author{
Jenny P. Castro ${ }^{1}$, Luis A. Franco ${ }^{1 *}$, Fredyc Diaz ${ }^{2}$ \\ ${ }^{1}$ Biological Evaluation of Promising Substances Group, Faculty of Pharmaceutical Sciences, Universidad de Cartagena, Cartagena, Colombia. \\ ${ }^{2}$ Laboratory of Phytochemical and Pharmacological Research, Faculty of Pharmaceutical Sciences, Universidad de Cartagena, Cartagena, Colombia.
}

\section{ARTICLE INFO \\ Received on: 23/09/2020 \\ Accepted on: 23/01/2021 \\ Available online: 05/04/2021}

\section{Key words:}

Natural products, noncommunicable diseases, inflammatory mediators, macrophages.

\begin{abstract}
Chronic inflammation has been recognized as an underlying pathophysiological mechanism in the initiation and progression of noncommunicable diseases, representing a significant morbidity and mortality cause worldwide. The prolonged use of anti-inflammatory drugs has been associated with different adverse effects, so there is a permanent need to develop new drugs to treat these pathologies. The anti-inflammatory potential of 37 extracts coming from 31 plant species from the Colombian Caribbean coast, was evaluated determining their ability to inhibit nitric oxide (NO) production using lipopolysaccharide (LPS) activated macrophages. The most active extracts were evaluated for their effect on the production of tumor necrosis factor (TNF- $\alpha$ ) and interleukins $1 \beta$ and 6 (IL-1 $\beta$ and IL-6) in macrophages. Fifteen extracts showed potent inhibitory activity of the production of NO, being the extracts of Ambrosia cumanensis, Trichilia hirta, Hyptis capitata (leaves and seeds), Mammea americana, and Crateva tapia, the most active extracts. The extracts of $A$. cumanensis and $M$. americana were considered promising, which significantly decreased the production of all proinflammatory cytokine evaluated. The species of A. cumanensis and M. americana are a promising source of molecules with anti-inflammatory activity. They should be evaluated in in vivo models of inflammation, as well as perform their fractionation to identify the compounds responsible for the activity.
\end{abstract}

\section{INTRODUCTION}

Inflammation is a fundamental component of the host defense mechanism against noxious stimuli. This process induces the proliferation and interaction of several types of cells and the release of various chemical mediators, including prostaglandins, leukotrienes, cytokines, chemokines, and nitric oxide (NO). Although the inflammatory response is necessary for the host's defense, when it occurs in an exacerbated manner, it constitutes a triggering factor for various chronic noncommunicable diseases (Calder, 2015).

Nonsteroidal anti-inflammatories and corticosteroids are the most commonly used groups of drugs for the treatment of inflammatory processes. Still, they also have numerous

"Corresponding Author

Luis A. Franco, Biological Evaluation of Promising Substances Group, Faculty of Pharmaceutical Sciences, Universidad de Cartagena, Cartagena,Colombia.E-mail:Ifrancoo@unicartagena.edu.co adverse effects, including heartburns, gastric and duodenal ulcers, cardiovascular diseases, kidney failure, osteoporosis, increase risk of susceptibility to infections, hyperglycemia, and obesity. This represents a problem for patients' health, causing alterations that sometimes are more serious than the initial condition, in addition to increasing the costs of long-term treatments. All these reasons justify the enormous efforts made worldwide to discover new therapeutic alternatives for the treatment of inflammatory processes (Manson et al., 2009; Shi et al., 2003), being natural products one of the main objectives because they have been, and still are a fundamental source in the discovery of drugs (Killeen et al., 2014). Consequently, many investigations have been mainly directed toward the screening of plant species as a strategy in search for metabolites with anti-inflammatory activity. This search for anti-inflammatories coming from natural sources is gaining more importance today due to the severe acute respiratory syndrome coronavirus 2 (SARS-CoV2) pandemic since the end of 2019, a virus that induces an exacerbated inflammatory process if adequate anti-inflammatory treatments are not received at the beginning of the infection. Colombia is one of the most mega- 
diverse countries in the world since it has a unique combination of geographic and topographical attributes that have allowed it to have an extraordinary diversity of flora (Gómez-Estrada et al., 2011). However, many of the medicinal properties of a high percentage of the plant species that make up the Colombian flora are still unknown.

Macrophages are one of the most important effector cells in the inflammatory response; however, during chronic inflammatory processes, they play an essential role in tissue damage in a large number of diseases that occur with inflammatory processes such as arthritis, atherosclerosis, obesity, cancer, diabetes, and inflammatory bowel disease (Kühl et al., 2015; Na et al., 2018; Treuter et al., 2017). Active macrophages produce various molecules, including the so-called reactive oxygen species and reactive nitrogen species (RNS), among which is NO, produced by the different isoforms of the enzyme nitric oxide synthase. The inducible isoform of nitric oxide synthase (iNOS) is responsible for the production of NO during the inflammatory response. The NO reacts with the superoxide radical anion $\left(\cdot \mathrm{O}_{2}^{-}\right)$ to produce peroxynitrite ion $\left(\mathrm{ONOO}^{-}\right)$, which plays an essential role in the host's defense. Peroxynitrite is a potent oxidizing agent that exerts its effects through the mutagenesis of microbial DNA, the inactivation of virulence factors, and the metabolic blockade in invading microorganisms, but due to its lack of specificity at high concentrations or when the synthesis occurs continuously, it produces tissue damage; this process being particularly well described in cardiovascular diseases especially in atherosclerosis (Bogdan, 2015; Lugrin et al., 2014). In vitro quantification of NO is inexpensive and quick in comparison with other mediators. Hence, its use to identified plant extracts with anti-inflammatory potential constitutes an important strategy that must be investigated. With the aim of exploring the ethnobotanical richness of our Caribbean region in search of new therapeutic agents with anti-inflammatory potential, in this work, we evaluated 31 plant species used in the traditional medicine of the Colombian Caribbean coast to treat various diseases related to inflammatory processes, determining their capacity to inhibit the production of the inflammatory mediator NO, in macrophages. In addition, the anti-inflammatory activity of the most active species (nitrite inhibition $>95 \%$ ) was confirmed, determining their effects on the production of the proinflammatory cytokines IL- $1 \beta$, IL-6, and TNF- $\alpha$ in LPSactivated RAW 264.7 cells.

\section{MATERIALS AND METHODS}

\section{Reagents}

Macrophages RAW 264.7 were acquired from the American Type Culture Collection (Manassas, VA). Penicillinstreptomycin, trypan blue, and lipopolysaccharide from Escherichia coli (LPS), N'-[[3-(aminomethyl)phenyl]methyl]ethanimidamide dihydrochloride (1400W), sodium nitrite, N-[1,1-naphthyl] ethylenediamine dihydrochloride, 4-aminobenzenesulfonamide, sodium nitroprusside (SNP), dexamethasone, rofecoxib, FolinCiocalteu, sodium carbonate, 2,2-diphenyl-1-picrylhydrazyl (DPPH), 6-hydroxy 2,5,7,8-tetramethylchroman-2-carboxylic acid (Trolox), 2,2'-azinobis-(3 ethylbenzothiazoline-6-sulfonic acid) (ABTS), and potassium persulfate $\left(\mathrm{K}_{2} \mathrm{~S}_{2} \mathrm{O}_{8}\right)$ were purchased from Sigma Aldrich (St Louis, MO). Bromide of 3[4,5-dimethylthiazol-2-yl]-2,5-diphenyltetrazolium (MTT) was obtained from Calbiochem ${ }^{\circledR}$ (San Diego, CA). Ethanol, dimethyl sulfoxide (DMSO), Dulbecco's modified eagle medium (DMEM), and fetal bovine serum (FBS) were obtained from Thermo Fisher Scientific (Pittsburgh, PA). ELISA kits from eBiosciences.

\section{Collection and identification of plant material}

Plant species were collected in the Caribbean coast of Colombia. The taxonomic identification was carried out in the Guillermo Piñeres Botanical Garden of Cartagena and the Colombian National Herbarium of the National Science Institute of the National University of Colombia; voucher specimens of each species were kept in the corresponding institution.

\section{Preparation of extracts and preliminary phytochemical analysis}

The previously dried and milled plant material was subjected to extraction by maceration with $96 \%$ ethanol at room temperature $\left(25^{\circ} \mathrm{C} \pm 3^{\circ} \mathrm{C}\right)$. The obtained extract was filtered and concentrated in a rotary evaporator under reduced pressure and controlled temperature $\left(40^{\circ} \mathrm{C}-45^{\circ} \mathrm{C}\right)$ and stored at $-20^{\circ} \mathrm{C}$. The following secondary metabolites' presence was determined qualitatively: alkaloids, coumarins, tannins, cardiotonic glycosides, flavonoids, saponins, triterpenes/steroids, and quinones, using a previously reported methodology (Herrera et al., 2014). Each analysis was carried out in triplicate.

\section{Effects on the production of NO and cytotoxicity in macrophages RAW 264.7}

RAW 264.7 macrophages were maintained in DMEM, enriched with $10 \%$ inactivated FBS, penicillin $(100 \mathrm{IU} / \mathrm{ml})$, and streptomycin $(100 \mu \mathrm{g} / \mathrm{ml})$, at $37^{\circ} \mathrm{C}$ and $5 \% \mathrm{CO}_{2}$. The viability of macrophages RAW 264.7, treated with different concentrations of the extracts, was determined using the method proposed by Ferrari et al. (1990), with some modifications (Ferrari et al., 1990).

The RAW 264.7 macrophages were seeded in 96-well plates $\left(2 \times 10^{4}\right.$ cells/well $)$ and incubated for 48 hours. Subsequently, the cells were washed with phosphate buffered saline (PBS) and treated with the extracts under study at different concentrations; Triton X-100 (20\%) was used as a positive cytotoxicity control. Thirty minutes later, the cells were stimulated with LPS $(1 \mu \mathrm{g} /$ $\mathrm{ml}$ ) and incubated for 24 hours. After this time, a $70 \mu \mathrm{l}$ aliquot of each well was preserved for subsequent determination of nitrite levels, and the cells were rewashed with PBS, and $100 \mu \mathrm{l}$ of the MTT solution $(250 \mu \mathrm{g} / \mathrm{ml})$ was added and incubated again for 4 hours. Finally, the supernatant was removed and the formazan crystals were dissolved with $100 \mu \mathrm{l}$ of DMSO and the absorbance was determined in a microplate reader (Multiskan GO, Thermo Scientific) at $\mathrm{DO}_{550}$. The evaluated extracts were considered cytotoxic when the percentage of cell survival was less than $80 \%$ (Ospina et al., 2013). The extracts' ability to inhibit NO production was determined by quantifying nitrite levels in supernatants from cell culture using the Griess reaction (Green et al., 1982). $70 \mu \mathrm{l}$ of Griess reagent was added to $70 \mu \mathrm{l}$ of the supernatant from the previously stored cell culture medium. The samples' absorbance was determined in a Multiskan GO microplate reader at $\mathrm{DO}_{550}$, and the concentration was calculated using a standard $\mathrm{NaNO}_{2}$ curve $(1-200 \mu \mathrm{M})$. The positive control was $1400 \mathrm{~W}(10 \mu \mathrm{M})$, a selective inhibitor of iNOS. 


\section{NO scavenging activity}

The scavenging activity of the most active extracts on NO was determined using the method described by Sreejayan and Rao (1997), with some modifications (Sreejayan and Rao, 1997). NO was generated spontaneously by SNP in an aqueous solution with physiological $\mathrm{pH}$, which in turn produces nitrite when interacting with oxygen, which can be easily determined using Griess reagent. The radical scavengers compete for the NO• radicals with the oxygen, with the consequent reduction in nitrite production. In summary, $1 \mathrm{ml}$ of $10 \mathrm{mM}$ SNP solution in PBS was mixed with $10 \mu \mathrm{l}$ of the extracts under study at the maximum concentration at which they were evaluated against RAW 264.7 macrophages in the model to determine their ability to inhibit NO mediator production. The mixture was left in incubation for 4 hours at room temperature, after which $100 \mu \mathrm{l}$ of this mixture was transferred to a 96-well plate, and $100 \mu 1$ of the Griess reagent was added. The $\mathrm{OD}_{550}$ was determined in a microplate reader (Multiskan GO, Thermo) and compared with a standard curve of sodium nitrite to calculate nitrite concentration.

\section{Quantification of phenolic compounds}

Folin-Ciocalteu's method was used for the quantification of phenolic compounds (Del-Toro-Sánchez et al., 2014). Briefly, $30 \mu \mathrm{l}$ of different concentrations of the extracts under study was taken and added to $150 \mu \mathrm{l}$ of a Folin-Ciocalteu solution $(0.1 \mathrm{M})$; the mixture was incubated at room temperature for 10 minutes, after which $120 \mu \mathrm{l}$ of a sodium carbonate solution $(7.5 \%)$ was added and incubated again for 2 hours. The $\mathrm{DO}_{760}$ was determined in a microplate reader (Multiskan GO, Thermo). The results are presented as mg of gallic acid per gram of dry extract.

\section{Determination of the antioxidant potential}

\section{$D P P H$ radical scavenging activity}

The DPPH• free radical scavenging capacity was determined using a standard method (Brand-Williams et al., 1995) with some modifications (Castro et al., 2019). In a 96-well microplate, $75 \mu \mathrm{l}$ of different concentrations of the extracts were mixed with $150 \mu \mathrm{l}$ of the DPPH methanolic solution $(100 \mu \mathrm{g} / \mathrm{ml})$. The mixture was incubated at room temperature for 30 minutes, after which the disappearance of the $\mathrm{DPPH} \bullet$ radical at $\mathrm{DO}_{550}$ was determined spectrophotometrically. The results were expressed as micromoles of Trolox per gram of dry extract.

\section{ABTS radical scavenging activity}

The $\mathrm{ABTS}^{-+}$radical scavenging activity was determined using a standard method (Re et al., 1999) with some modifications (Castro et al., 2019). The $\mathrm{ABTS}^{\cdot+}$ radical originates by reacting ABTS $(7 \mathrm{mM})$ with potassium persulfate $(2.45 \mathrm{mM})$ incubated at $4^{\circ} \mathrm{C}$ in the dark for 16 hours. The solution of the $\mathrm{ABTS}^{++}$radical was diluted with ethanol to obtain an absorbance value of $0.70 \pm$ 0.01 at $734 \mathrm{~nm} ; 180 \mu \mathrm{l}$ of this solution was mixed with $20 \mu \mathrm{l}$ of the solutions with different concentrations of the extracts under study. The mixture was incubated at room temperature for 30 minutes, after which the disappearance of the $\mathrm{ABTS}^{\cdot+}$ radical to $\mathrm{DO}_{734}$ was determined spectrophotometrically. The results are presented as micromoles of Trolox per gram of dry extract.

\section{Quantification of cytokines and PGE2}

Macrophages RAW 264.7 were seeded in 24-well plates $\left(2 \times 10^{5}\right.$ cells/well $)$ and incubated for 24 hours. After that time, cells were treated with the extracts and incubated for 30 minutes, activated with LPS $(1 \mu \mathrm{g} / \mathrm{ml})$, and incubated again for 24 hours to produce the inflammatory mediators (IL-1 $\beta$, IL-6, TNF- $\alpha$, and PGE2). The culture supernatants were collected and kept at $-20^{\circ} \mathrm{C}$ until further analysis. The production of IL-1 $\beta$, IL- 6 , TNF- $\alpha$, and PGE2 was measured using a standard sandwich ELISA procedure following the manufacturer's instructions of kits from eBiosciences (San Diego, CA). Dexamethasone and rofecoxib were used as positive controls and evaluated under the same conditions.

\section{Statistical analysis}

The results are expressed as the mean \pm standard error of the mean (SEM) of three independent experiments. Data were analyzed using one-way analysis of variance (ANOVA), followed by Dunnett's post hoc test. Values of $p<0.05$ were considered significant.

\section{RESULT AND DISCUSSION}

Colombia has an enormous biological diversity and is considered one of the 17 "mega-diverse countries" in the world, according to the United Nations Environment Program. Large amounts of data about Colombia's ecosystems are being collected in the "Colombia BIO" expeditions, including novel biodiversity in previously unexplored regions due to the internal conflict. Unfortunately, for a high percentage of these species, there is sparse knowledge, which has avoided taking advantage of the benefits in the food, medicine, and industry (De Vega et al., 2020). An alternative way to take advantage of these biological resources is the practice of bioprospecting, which implies the interaction between different types of knowledge, especially ancestral knowledge that local and indigenous communities in South American countries have, with the scientific knowledge contributed by the academic and industrial sectors, especially the pharmaceutical industry (Duarte and Velho, 2008). To contribute to the bioprospecting of our natural resources and in accordance with the permanent need to develop new drugs with anti-inflammatory properties, in this work, we selected 31 plant species used in the popular medicine of the Colombian Caribbean coast to assess its anti-inflammatory potential.

\section{Collection, identification of plant material, and extract preparation}

Information on the collected species, including common names, the part of the plant evaluated, the collection site, the species' registration codes, and the yields of the extracts obtained, is presented in Table 1 and their preliminary phytochemical analysis is presented in Table 2.

\section{Effect on RAW 264.7 cell viability}

As shown in Figure 1, only the extracts of Momordica charantia, Inga vera, Ambrosia cumanensis (seeds and leaves), Trichilia hirta, Tabernaemontana cymosa (seeds), and Anacardium occidentale showed toxicity (cell viability under $80 \%$ ) on RAW 264.7 macrophages at $100 \mu \mathrm{g} / \mathrm{ml}$. Therefore, these extracts were 
Table 1. Information on vegetable species in the study.

\begin{tabular}{|c|c|c|c|c|c|c|}
\hline Scientific name & Family & Local name & Part used & Voucher number & Extract yields (\%) & Collection site \\
\hline Crotalaria retusa $\mathrm{L}$. & Fabaceae & Cascabelito & Seeds & JBC 12007 & 8.7 & Galerazamba, Bolívar. \\
\hline Heliotropium indicum $\mathrm{L}$. & Boraginaceae & Rabo de alacran & Seeds & JBC 3691 & 6.8 & $\left(10^{\circ} 47^{\prime} 22^{\prime \prime} \mathrm{N}, 75^{\circ} 15^{\prime} 35^{\prime \prime} \mathrm{W}\right)$ \\
\hline Mammea americana $L$. & Calophyllaceae & Mamey & Leaves & JBC 467 & 7.3 & \\
\hline Murraya exotica $L$. & Rutaceae & Azahar de la india & Leaves & COL 538418 & 6.3 & \\
\hline Pedilanthus tithymaloides (L.) Poit. & Euforbiaceae & Pitamorreal & Leaves & JBC 1018 & 8.1 & \\
\hline Momordica charantia $L$. & Cucurbitaceae & Balsamina & Leaves & JBC 793 & 9.8 & $\begin{array}{c}\text { San Basilio de Palenque, Bolívar. } \\
\left(10^{\circ} 6^{\prime} 12^{\prime \prime} \mathrm{N}, 75^{\circ} 11^{\prime} 56^{\prime \prime} \mathrm{W}\right)\end{array}$ \\
\hline \multirow[t]{2}{*}{ Ambrosia cumanensis Kunth. } & \multirow[t]{2}{*}{ Asteraceae } & \multirow[t]{2}{*}{ Artemisa } & Leaves & COL 538448 & 5.8 & \multirow{2}{*}{$\begin{array}{l}\text { San Bernardo del viento, Córdoba. } \\
\left(9^{\circ} 21^{\prime} 18^{\prime \prime} \mathrm{N}, 75^{\circ} 57^{\prime} 16^{\prime \prime} \mathrm{W}\right)\end{array}$} \\
\hline & & & Seeds & COL 538448 & 9.8 & \\
\hline Anacardium occidentale $L$. & Anacardiaceae & Marañon & Seeds & JBC 4431 & 7.5 & \\
\hline Annona squamosa $\mathrm{L}$. & Annonaceae & Guanabana & Seeds & JBC 4431 & 8.0 & \\
\hline Bursera graveolens Kunth. & Burseraceae & Caraña & Bark & JBC 5115 & 7.9 & \\
\hline Bursera simaruba (L.) Sarg & Burseraceae & Almácigo & Bark & JBC 4458 & 6.5 & \\
\hline Caesalpinia coriaria (Jacq.) Willd. & Fabaceae & Dividivi & Fruit & COL 538422 & 8.2 & \\
\hline Capparis odoratissima (Jacq.) Hutch. & Capparaceae & Olivo & Leaves & JBC 1492 & 7.6 & \\
\hline Chenopodium ambrosioides $\mathrm{L}$. & Amaranthaceae & Paico & Leaves & JBC 4005 & 9.4 & \\
\hline \multirow[t]{2}{*}{ Cecropia peltata $\mathrm{L}$. } & \multirow[t]{2}{*}{ Urticaceae } & \multirow[t]{2}{*}{ Yarumo } & Leaves & JBC 1383 & 7.8 & \\
\hline & & & Bark & JBC 1383 & 7.8 & \\
\hline Crateva tapia $L$. & Capparaceae & Naranjuelo & Leaves & JBC 12017 & 6.4 & \\
\hline Diospyros inconstans Jacq. & Ebenaceae & Caimitillo & Bark & JBC 1438 & 10.2 & \\
\hline Eryngium foetidum $L$. & Apiaceae & Culantro & Leaves & COL 538419 & 8.8 & \\
\hline Gustavia superba (Kunth) O.Berg. & Lecythidaceae & Membrillo & Leaves & JBC 1382 & 6.8 & \\
\hline \multirow[t]{3}{*}{ Hippomane mancinella $\mathrm{L}$. } & \multirow[t]{3}{*}{ Euphorbiaceae } & \multirow[t]{3}{*}{ Manzanillo } & Leaves & JBC 2478 & 6.7 & \\
\hline & & & Fruit & JBC 2478 & 5.4 & \\
\hline & & & Seeds & JBC 2478 & 8.7 & \\
\hline Hura crepitans $\mathrm{L}$. & Euphorbiaceae & Ceiba blanca & Bark & JBC 788 & 7.2 & \\
\hline \multirow[t]{2}{*}{ Hyptis capitata Jacq. } & \multirow[t]{2}{*}{ Lamiaceae } & \multirow[t]{2}{*}{ Botón negro } & Leaves & JBC 2478 & 10.4 & \\
\hline & & & Seeds & JBC 2478 & 9.8 & \\
\hline Inga vera Willd. & Fabaceae & Guama & Seeds & JBC 17149 & 8.1 & \\
\hline Piper peltatum $\mathrm{L}$. & Piperaceae & Santa María & Leaves & JBC 1438 & 4.2 & \\
\hline Ruellia tuberosa $\mathrm{L}$. & Acanthaceae & Campana & Leaves & JBC 3932 & 6.8 & \\
\hline Sarcostemma clausum (Jacq.) Schult. & Apocynaceae & Bejuco de sapo & Leaves & JBC 2502 & 7.3 & \\
\hline Sterculia apetala (Jacq.) H. Karst. & Malvaceae & Camajuro & Seeds & COL 538417 & 7.8 & \\
\hline Tabebuia ochracea (Cham.) Standl. & Bignoniaceae & Polvillo & Bark & JBC 5153 & 6.8 & \\
\hline \multirow[t]{2}{*}{ Tabernaemontana cymosa Jacq. } & \multirow[t]{2}{*}{ Apocynaceae } & \multirow[t]{2}{*}{ Bola de puerco } & Seeds & JBC 3243 & 9.6 & \\
\hline & & & Bark & JBC 3243 & 7.3 & \\
\hline Thevetia peruviana (Pers.) Merr. & Apocynaceae & Cavalonga & Flowers & JBC 66 & 7.4 & \\
\hline Trichilia hirta L. & Meliaceae & Jobo macho & Seeds & JBC 4330 & 7.9 & \\
\hline
\end{tabular}

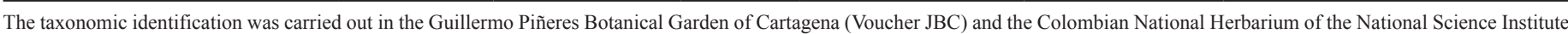
of the National University of Colombia (Voucher COL). The yields were calculated as follows: [Dry Concentrated Extract $(\mathrm{g}) /$ Dry Material $(\mathrm{g})] \times 100$.

evaluated to determine their highest nontoxic concentration and their anti-inflammatory effect on macrophages RAW 264.7 was securely evaluated. The selected concentration of each extract can be seen in Table 3 .

\section{Effect on NO production in RAW 264.7 macrophages}

The anti-inflammatory potential of the extracts was established by determining their effect on the release of the NO inflammatory mediator in the RAW 264.7 macrophage cell line. When macrophages are stimulated, they produce NO, which is important in protecting the organism against viruses and pathogenic microorganisms (Bogdan, 2015; Wallace, 2005). The antiviral or antimicrobial effect of NO and other RNS such as peroxynitrite is related to their ability to react with structural elements, components of the replication machinery, metabolic enzymes, and molecules associated with the virulence of infectious pathogens (Bogdan, 2015). However, NO when it is in high concentrations or when it is produced continuously, as it happens during chronic inflammatory processes, can produce harmful results for the tissues, being able to react with the superoxide free radical $\left(\mathrm{O}^{2-}\right)$ 
Table 2. Phytochemical characterization of vegetable species in the study.

\begin{tabular}{|c|c|c|c|c|c|c|c|c|c|}
\hline \multirow{2}{*}{ Scientific name } & \multirow{2}{*}{$\begin{array}{l}\text { Part } \\
\text { used }\end{array}$} & \multicolumn{8}{|c|}{ Metabolite } \\
\hline & & Alkaloids & Coumarins & Tannins & Glycosides & Flavonoids & Saponins & Terpenes/steroids & Quinones \\
\hline \multirow[t]{2}{*}{ A. cumanensis } & Leaves & - & - & - & + & - & + & + & + \\
\hline & Seeds & + & + & + & - & + & - & + & - \\
\hline A. occidentale & Seeds & - & + & + & - & + & + & + & - \\
\hline A. squamosa & Seeds & + & + & + & - & + & + & + & - \\
\hline B. graveolens & Bark & - & + & - & + & + & - & - & + \\
\hline B. simaruba & Bark & + & - & - & - & + & + & + & + \\
\hline C. coriaria & Fruit & - & - & + & + & - & - & - & + \\
\hline C. odoratissima & Leaves & + & + & - & - & - & - & + & - \\
\hline C. ambrosioides & Leaves & - & - & - & - & + & - & - & - \\
\hline \multirow[t]{2}{*}{ C. peltata } & Leaves & + & - & + & + & + & + & + & + \\
\hline & Bark & + & + & - & + & + & + & + & - \\
\hline C. tapia & Leaves & + & + & - & + & - & + & - & - \\
\hline C. retusa & Seeds & + & - & - & - & + & + & - & - \\
\hline D. inconstans & Bark & + & + & + & - & - & + & + & - \\
\hline E. foetidum & Leaves & - & - & - & + & - & - & + & + \\
\hline G. superba & Leaves & + & - & - & - & - & - & + & - \\
\hline H. indicum & Seeds & - & - & - & + & + & - & - & + \\
\hline \multirow[t]{3}{*}{ H. mancinella } & Leaves & + & + & + & + & + & - & + & - \\
\hline & Fruit & - & + & - & - & - & + & + & - \\
\hline & Seeds & + & + & + & + & + & - & - & + \\
\hline H. crepitans & Bark & + & + & + & + & + & - & - & + \\
\hline \multirow[t]{2}{*}{ H. capitata } & Leaves & + & + & + & - & + & + & - & - \\
\hline & Seeds & + & + & - & + & + & - & - & + \\
\hline I. vera & Seeds & - & + & - & - & + & - & - & - \\
\hline M. americana & Leaves & - & + & + & + & + & + & + & - \\
\hline M. charantia & Leaves & + & - & - & + & - & - & + & - \\
\hline M. exotica & Leaves & + & + & - & - & + & + & + & - \\
\hline P. tithymaloides & Leaves & + & - & + & + & + & - & - & + \\
\hline P. peltatum & Leaves & + & - & + & + & + & + & + & + \\
\hline R. tuberosa & Leaves & - & - & + & - & + & + & + & + \\
\hline S. clausum & Leaves & - & - & - & + & + & - & - & + \\
\hline S. apetala & Seeds & + & + & + & - & + & - & - & - \\
\hline T. ochracea & Bark & - & - & + & - & + & - & - & + \\
\hline \multirow[t]{2}{*}{ T. cymosa } & Seeds & + & - & - & + & + & + & + & + \\
\hline & Bark & + & + & + & + & - & + & - & - \\
\hline T. peruviana & Flowers & - & - & - & + & + & - & - & + \\
\hline T. hirta & Seeds & + & + & - & + & - & + & + & - \\
\hline
\end{tabular}

+ : presence and - : not detected.

to generate the peroxynitrite anion $\left(\mathrm{ONOO}^{-}\right)$, from which the formation of hydroxyl radicals $(\bullet \mathrm{OH})$, carbonate $\left(\mathrm{CO}_{3}{ }^{-}\right)$, and nitrogen dioxide $\left(\cdot \mathrm{NO}_{2}\right)$ can be derived. These free radicals can interact with proteins, lipids, and nucleic acids, promoting various molecular modifications responsible for altering the cells' biological functions, leading to the appearance of various chronic diseases. Therefore, the iNOS inhibitors could have a therapeutic application in conditions that occur with chronic inflammatory processes such as arthritis, inflammatory bowel disease, and cancer (Bogdan, 2015; Lugrin et al., 2014).
The effect of the extracts under study on the inhibition of NO production in macrophages RAW 264.7 is presented in Table 3. The extracts were classified according to their activity as active $(\%$ inhibition $\geq 60)$, moderate $(60>\%$ inhibition $>40)$, mild $(40>\%$ inhibition $>20)$, and inactive $(\%$ inhibition $<20)$. Fifteen extracts corresponding to $40.5 \%$ of all the extracts evaluated were classified as actives, being the extracts of $A$. cumanensis (seeds), T. hirta (seeds), Hyptis capitata (seeds and leaves), Mammea americana (leaves), and Crateva tapia (leaves) the most active, with inhibition values greater than $95 \%$, presenting itself as powerful inhibitors 


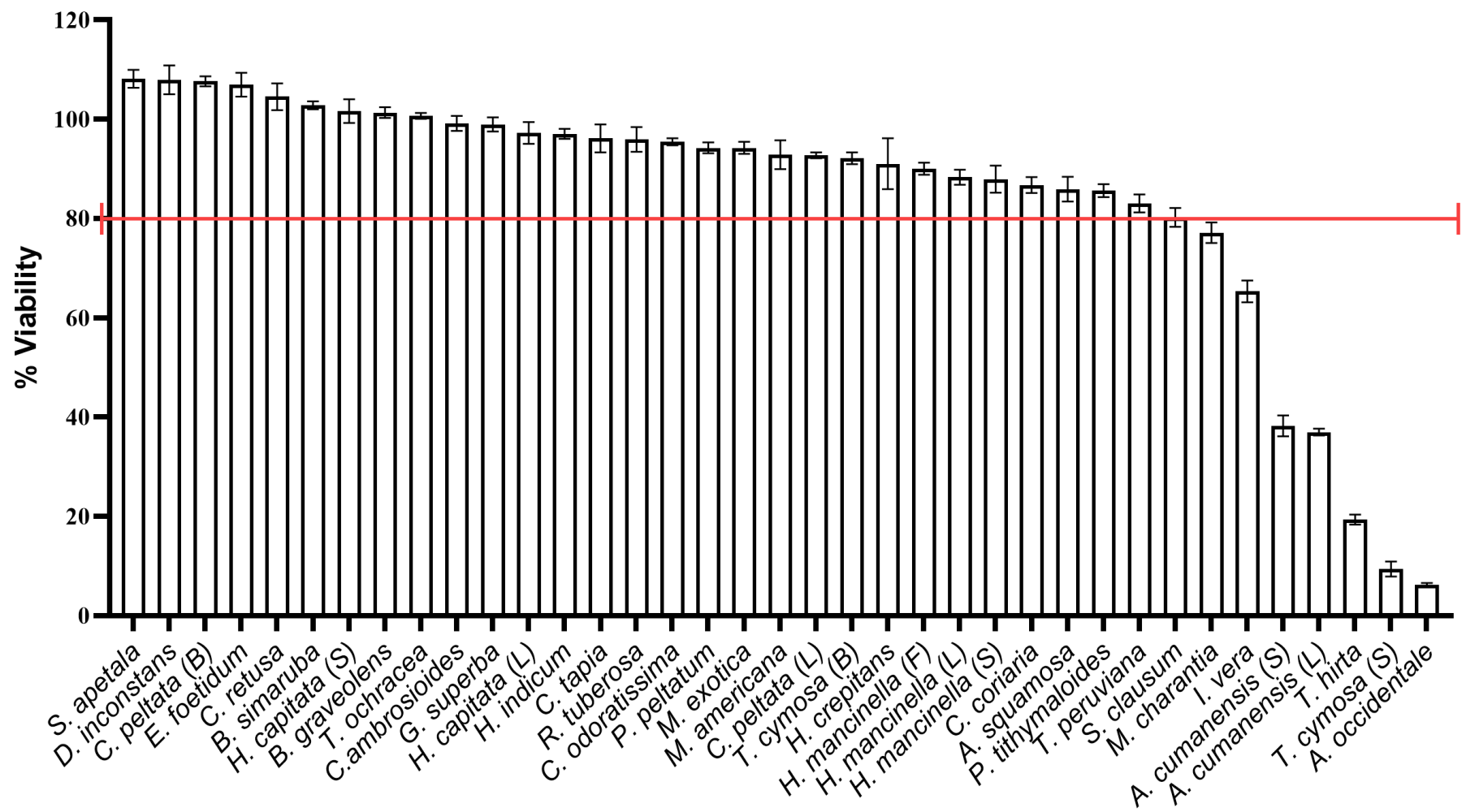

Figure 1. Effect of extracts on cell viability of RAW 264.7 macrophages. (S): seeds; (L): leaves; (B) bark; (F) fruit. Cytotoxicity was measured with MTT assay. Each value represents mean $\pm \operatorname{SEM}(n=9)$

of the production of NO in vitro, and therefore, they could be the basis for developing new therapies to prevent the oxidation of macromolecules mediated by the NO during the chronic inflammatory processes; characteristic condition of pathologies such as cancer, diabetes, and inflammatory bowel disease. Plant species to which the most active extracts belong are widely used in traditional medicine to treat various health conditions (Table 4), including some related to chronic inflammatory processes. It is important to highlight the potent activity shown by the extracts of A. cumanensis (seeds) and T. hirta (seeds), which exerted their inhibitory effect at lower concentrations $(25$ and $12 \mu \mathrm{g} / \mathrm{ml})$ than the required for the other extracts $(100 \mu \mathrm{g} / \mathrm{ml})$. The rest of evaluated extracts showed moderate activity (4 extracts, $10.8 \%$ ) or mild activity ( 8 extracts, $21.6 \%$ ) or were inactive (10 extracts, $27.0 \%$ ).

\section{Quantification of phenolic compounds and determination of free radical scavenging capacity}

Phenolic compounds are widely known for their antioxidant effects, mainly associated with their free radical scavenging capacity and their impact on the decrease of various inflammatory mediators, including NO (Conforti and Menichini, 2011; Fernandez-Panchon et al., 2008). The content of total phenolic compounds, as well as their scavenger activity on DPPH and ABTS free radicals, was quantified in the extracts considered as active, observing a strong correlation between the presence of the phenolic compounds and the scavenger effect of free radicals DPPH $(r=0.86)$ and ABTS $(r=0.91)$; in fact, extracts of $A$. occidentale (seeds), Bursera simaruba (bark), $H$. capitata (seeds), and $M$. americana (leaves) showed the highest content of phenolic components as well as the best DPPH• and $\mathrm{ABTS}^{++}$radical scavenging activity (Table 5). With respect to the NO scavenging activity, a low correlation $(r=0.27)$ between the phenolic compounds content and this scavenging activity was observed (Table 6). Therefore, the effect on the inhibition of NO• production in LPS-induced RAW 264.7 macrophages is related to the impact on cells and not with the scavenging effects of NO by the active extracts.

In addition, phenolic compounds content showed a low correlation ( $r=0.10)$ with the inhibition of the NO production by the macrophages RAW 264.7, in such a way that there is no direct relationship between the activity shown by extracts and the total phenolic content present in the extracts; for instance, extracts such as A. cumanensis (seeds and leaves), T. hirta (seeds), $H$. capitata (leaves), C. tapia (leaves), Murraya exotica (leaves), and Eryngium foetidum (leaves) that showed potent inhibitory activity of NO production in the cell line ( $\%$ inhibition $\geq 90 \%)$ had a low content of phenolic compounds in their composition ( $<30 \mathrm{mg}$ of gallic acid/g of extract), while the extract of $A$. occidentale (seeds) that showed the highest content of phenolic compounds only inhibited in $60.28 \%$ of the NO in the cells. This low correlation is not sufficient reason to rule out that this group of metabolites can be associated with this biological activity since this not only depends on the concentration at 
Table 3. Effect of evaluated extracts on the production intracellular of NO in LPS-stimulated RAW 264.7 macrophages.

\begin{tabular}{|c|c|c|c|c|c|}
\hline Scientific name & Part used & Concentration $(\mu \mathrm{g} / \mathrm{ml})$ & Cell viability (\%) & Nitrite inhibition (\%) & Classification \\
\hline A. cumanensis & Seeds & 25 & $95.8 \pm 3.1$ & $113.6 \pm 0.8$ & Active \\
\hline T. hirta & Seeds & 12 & $91.0 \pm 3.3$ & $108.2 \pm 1.4$ & \\
\hline H. capitata & Leaves & 100 & $97.2 \pm 2.2$ & $101.6 \pm 0.7$ & \\
\hline H. capitata & Seeds & 100 & $101.6 \pm 2.4$ & $100.3 \pm 0.7$ & \\
\hline M. americana & Leaves & 100 & $92.8 \pm 2.9$ & $97.8 \pm 2.4$ & \\
\hline C. tapia & Leaves & 100 & $96.1 \pm 2.8$ & $95.0 \pm 5.8$ & \\
\hline A. cumanensis & Leaves & 25 & $94.0 \pm 0.7$ & $93.0 \pm 0.8$ & \\
\hline B. simaruba & Bark & 100 & $102.8 \pm 0.8$ & $92.8 \pm 1.1$ & \\
\hline M. exotica & Leaves & 100 & $94.2 \pm 1.2$ & $91.6 \pm 5.3$ & \\
\hline E. foetidum & Leaves & 100 & $106.9 \pm 2.4$ & $90.4 \pm 1.8$ & \\
\hline A. squamosa & Seeds & 100 & $85.9 \pm 2.5$ & $74.2 \pm 3.7$ & \\
\hline H. indicum & Seeds & 100 & $97.0 \pm 1.0$ & $66.6 \pm 3.8$ & \\
\hline C. peltata & Leaves & 100 & $92.7 \pm 0.6$ & $66.2 \pm 1.9$ & \\
\hline A. occidentale & Seeds & 50 & $106.3 \pm 5.7$ & $60.3 \pm 1.8$ & \\
\hline C. ambrosioides & Leaves & 100 & $99.1 \pm 1.5$ & $60.0 \pm 2.0$ & \\
\hline H. mancinella & Leaves & 100 & $88.3 \pm 1.5$ & $48.2 \pm 2.8$ & Moderately active \\
\hline C. peltata & Bark & 100 & $107.6 \pm 1.0$ & $44.8 \pm 2.7$ & \\
\hline T. сутоsa & Bark & 100 & $92.1 \pm 1.2$ & $41.0 \pm 4.8$ & \\
\hline D. inconstans & Bark & 100 & $107.9 \pm 2.9$ & $40.7 \pm 2.8$ & \\
\hline R. tuberosa & Leaves & 100 & $95.9 \pm 2.5$ & $38.1 \pm 1.9$ & Mildly active \\
\hline C. odoratissima & Leaves & 100 & $95.4 \pm 0.7$ & $34.2 \pm 3.6$ & \\
\hline M. charantia & Leaves & 50 & $97.4 \pm 3.2$ & $30.3 \pm 2.3$ & \\
\hline H. crepitans & Bark & 100 & $91.0 \pm 5.1$ & $27.1 \pm 2.3$ & \\
\hline P. peltatum & Leaves & 100 & $94.2 \pm 1.1$ & $22.6 \pm 3.6$ & \\
\hline C. coriaria & Fruit & 100 & $86.7 \pm 1.6$ & $21.2 \pm 3.4$ & \\
\hline G. superba & Leaves & 100 & $98.9 \pm 1.4$ & $20.8 \pm 1.9$ & \\
\hline C. retusa & Seeds & 100 & $104.5 \pm 2.7$ & $20.2 \pm 2.9$ & \\
\hline H. mancinella & Seeds & 100 & $87.9 \pm 2.7$ & $17.8 \pm 1.9$ & Inactive \\
\hline S. apetala & Seeds & 100 & $108.1 \pm 1.8$ & $15.1 \pm 3.7$ & \\
\hline I. vera & Seeds & 25 & $84.8 \pm 2.8$ & $13.5 \pm 2.0$ & \\
\hline T. cymosa & Seeds & 50 & $84.8 \pm 0.7$ & $11.3 \pm 1.9$ & \\
\hline B. graveolens & Bark & 100 & $101.3 \pm 1.1$ & $8.1 \pm 1.0$ & \\
\hline S. clausum & Leaves & 100 & $80.2 \pm 1.9$ & $7.0 \pm 3.1$ & \\
\hline H. mancinella & Fruit & 100 & $90.0 \pm 1.2$ & $5.2 \pm 1.6$ & \\
\hline T. peruviana & Flowers & 100 & $83.0 \pm 1.8$ & $0.2 \pm 5.6$ & \\
\hline P. tithymaloides & Leaves & 100 & $85.6 \pm 1.3$ & 0.0 & \\
\hline T. ochracea & Bark & 100 & $100.6 \pm 0.6$ & 0.0 & \\
\hline
\end{tabular}

The results represent the mean $\pm \operatorname{SEM}(n=12)$ from three independent experiments. Active $(\%$ inhibition $\geq 60)$, moderate $(60>\%$ inhibition $>40)$, mild $(40>\%$ inhibition $>20)$, and inactive $(\%$ inhibition $<20)$.

which the phenolic compounds are found but also on their structure, of which there are more than 8,000 known structures, in a range from simple molecules, such as phenolic acids, to highly polymerized compounds, such as condensed tannins (Conforti and Menichini, 2011; Sofi and Nabi, 2018). In fact, several phenolic compounds, including resveratrol, isovitexin, isoliquiritigenin, baicalin, baicalein, wogonin, apigenin, and luteolin, have shown the ability to inhibit the iNOS expression and NO production in LPS-induced RAW 264.7 macrophages (Conforti and Menichini, 2011).

\section{Determination of inflammatory mediators}

The most active extracts (nitrite inhibition > 95\%) with anti-inflammatory potential were evaluated to identify their effects on the inflammatory mediators IL- 6 , TNF- $\alpha$, and IL- $1 \beta$, which is the same as NO, increase their production by activating the transcription factor NF- $\mathrm{KB}$ in LPS-induced macrophages (Girón et al., 2010). Results show that all evaluated extracts significantly decreased the production of IL-6, being the extracts of $A$. cumanensis (seeds) and $T$. hirta (seeds) the most potent, with inhibition percentages greater than $90 \%$, with activity higher than 
Table 4. Summary of ethnopharmacological antecedents of the most active plant species.

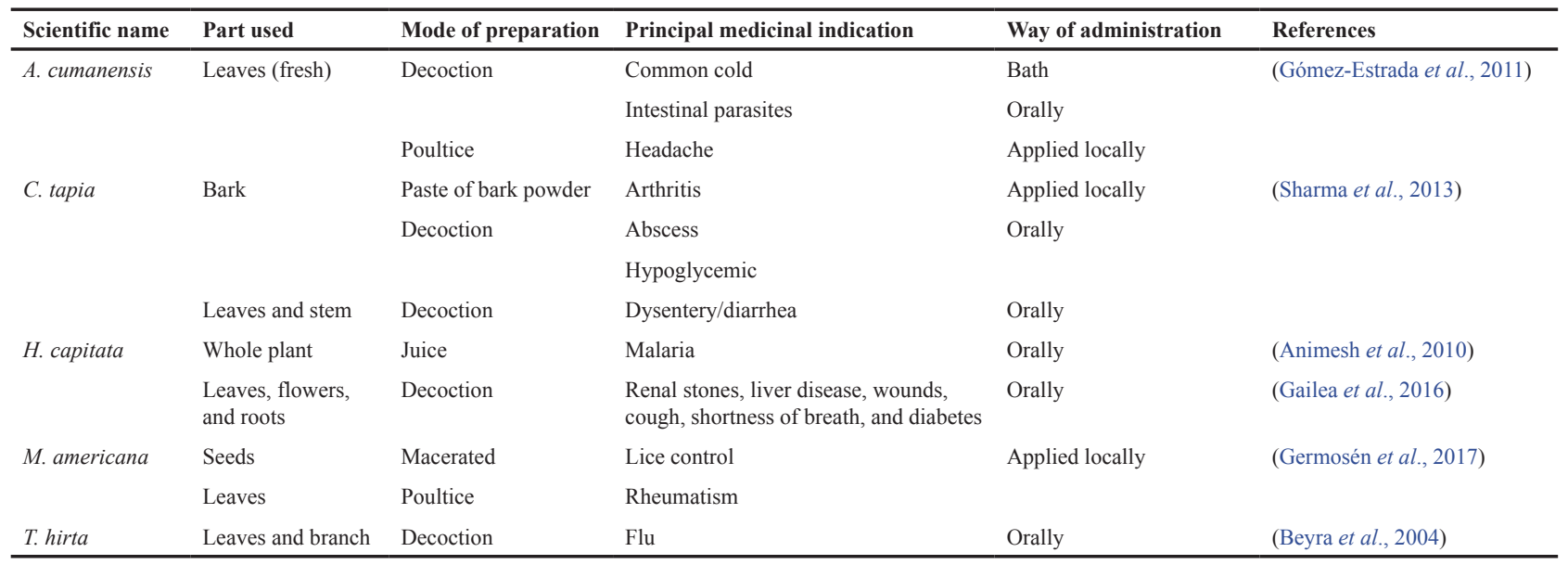

Table 5. Quantification of phenolic compounds and scavenging effect on DPPH and ABTS radicals of the active extracts.

\begin{tabular}{|c|c|c|c|c|}
\hline Scientific name & Part used & $\begin{array}{c}\text { Phenolic compounds } \\
\text { (mg of gallic acid/g of extract) }\end{array}$ & $\begin{array}{c}\text { DPPH } \\
(\mu \text { moles Trolox } / g \text { of extract })\end{array}$ & $\begin{array}{c}\text { ABTS } \\
\text { ( } \mu \text { moles Trolox } / g \text { of extract) }\end{array}$ \\
\hline A. occidentale & Seeds & $142.9 \pm 2.4$ & $1,652.2 \pm 28.5$ & $1,028.1 \pm 19.4$ \\
\hline B. simaruba & Bark & $106.3 \pm 2.4$ & $831.6 \pm 14.6$ & $1,551.3 \pm 22.2$ \\
\hline M. americana & Leaves & $97.3 \pm 2.6$ & $323.5 \pm 6.7$ & $1,155.0 \pm 14.9$ \\
\hline H. capitata & Seeds & $96.8 \pm 0.9$ & $279.2 \pm 3.1$ & $769.1 \pm 10.3$ \\
\hline C. peltata & Leaves & $53.0 \pm 1.3$ & $176.6 \pm 4.1$ & $207.3 \pm 4.4$ \\
\hline H. capitata & Leaves & $30.0 \pm 0.7$ & $161.8 \pm 1.4$ & $158.8 \pm 2.6$ \\
\hline A. cumanensis & Leaves & $26.4 \pm 0.5$ & $75.6 \pm 1.8$ & $51.8 \pm 2.1$ \\
\hline A. cumanensis & Seeds & $23.3 \pm 0.5$ & $43.9 \pm 0.7$ & $127.9 \pm 3.4$ \\
\hline C. ambrosioides & Leaves & $19.8 \pm 0.3$ & $43.5 \pm 0.4$ & $77.2 \pm 0.9$ \\
\hline E. foetidum & Leaves & $19.7 \pm 6.2$ & $96.3 \pm 1.0$ & $220.6 \pm 3.3$ \\
\hline T. hirta & Seeds & $15.7 \pm 0.9$ & $11.5 \pm 0.2$ & $23.0 \pm 0.4$ \\
\hline C. tapia & Leaves & $7.5 \pm 0.1$ & $15.7 \pm 0.2$ & $45.5 \pm 0.5$ \\
\hline H. indicum & Seeds & $3.3 \pm 0.1$ & nd & $34.8 \pm 0.2$ \\
\hline A. squamosa & Seeds & $1.2 \pm 0.0$ & nd & nd \\
\hline
\end{tabular}

The results represent the mean $\pm \operatorname{SEM}(n=9)$ from three independent experiments. $\mathrm{nd}=$ not determined.

Table 6. Scavenging effect of the active extracts on nitric oxide.

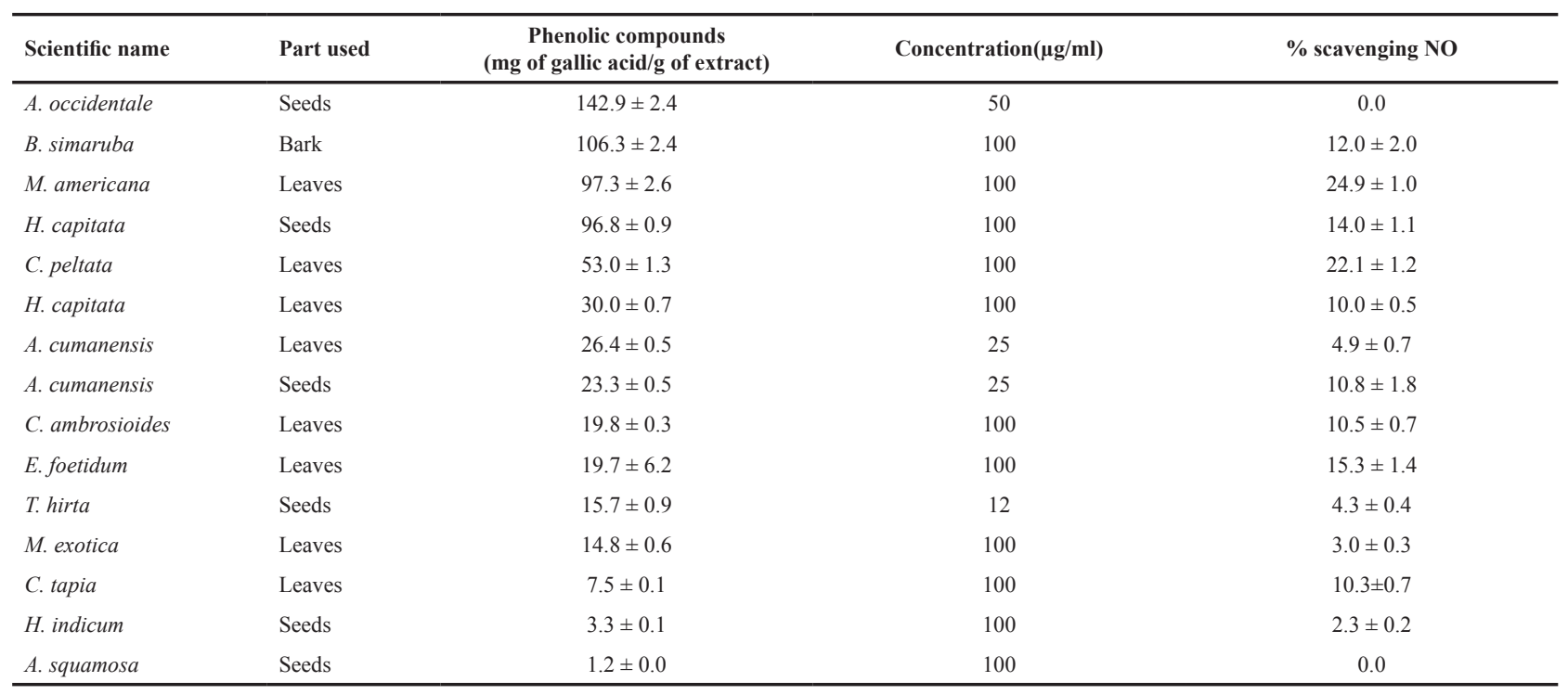

The results represent the mean $\pm \operatorname{SEM}(n=9)$ from three independent experiments. 
A

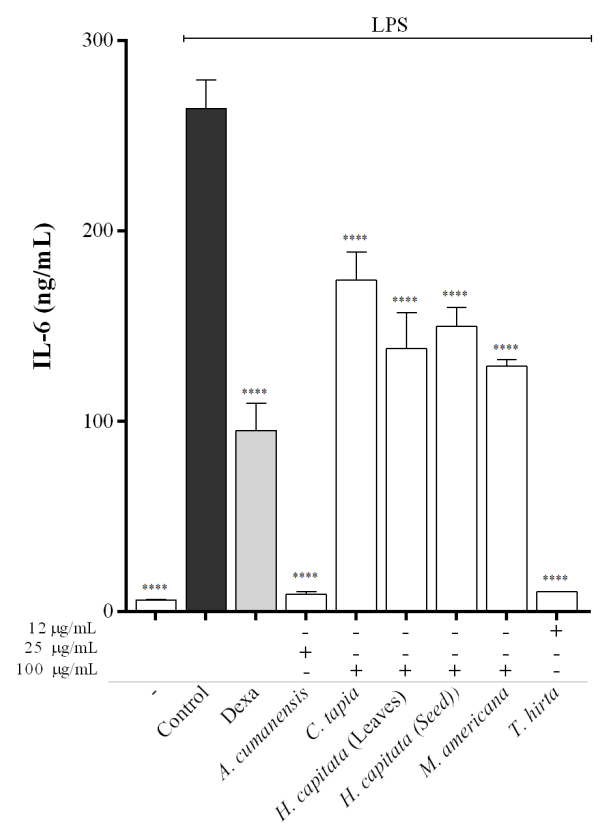

B

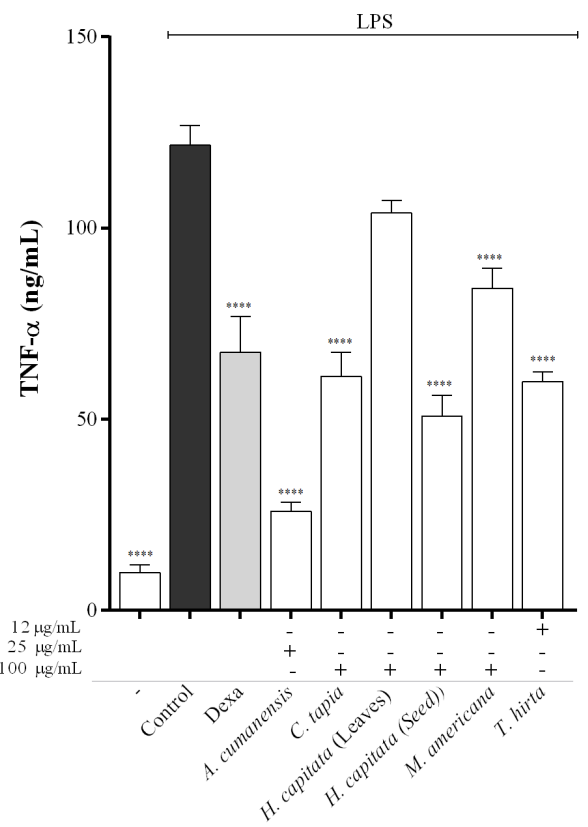

C

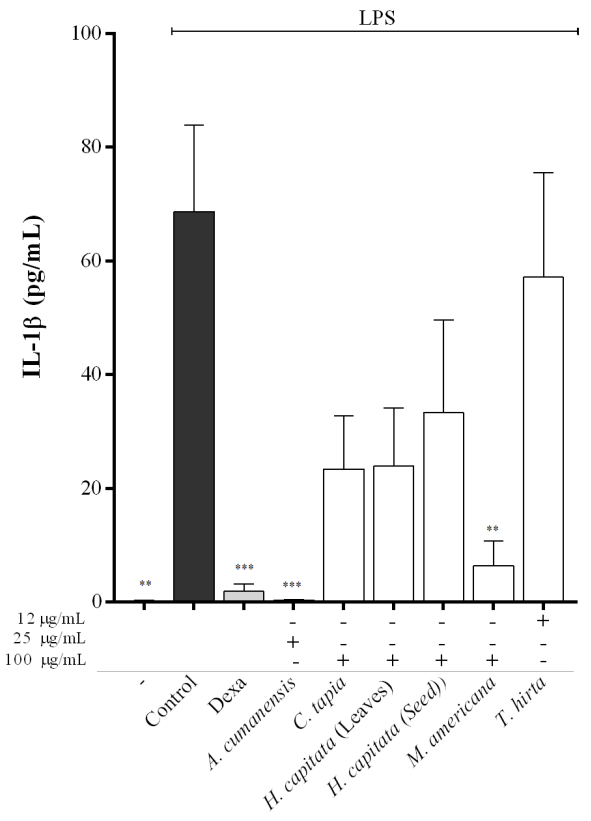

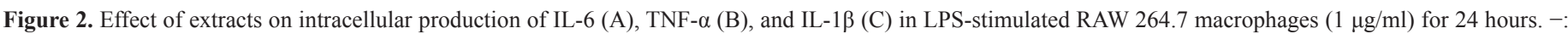

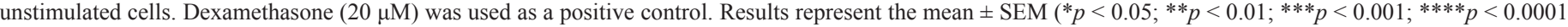
ANOVA statistically significant compared with LPS-treated group).

shown by dexamethasone (68\%) used as a reference drug (Fig. 2A). Regarding the effect on TNF- $\alpha$, except for the extract of $H$. capitata (leaves), all others significantly inhibited the production of this mediator with similar percentages to that shown by the reference drug (Fig. 2B). Finally, the results presented in Figure $2 \mathrm{C}$ show that only $A$. cumanensis (seeds) and $M$. americana (seeds) extracts inhibited the production of IL-1 $\beta$ significantly. Inflammatory mediators IL-6, IL- $1 \beta$, and TNF- $\alpha$ are produced by many cell types, mainly macrophages and mast cells. They have several roles in the inflammatory response, including activation of the endothelium and leukocytes and induction of the acute phase response (Medzhitov, 2008).

The simultaneous inhibition of the production of these proinflammatory cytokines, as in the case of the extracts of $A$. cumanensis (seeds) and M. americana (leaves) (Fig. 2), is a key point as a pharmacological target in the treatment of inflammation. Therefore, we evaluated the concentration-dependent effect of these two extracts on these proinflammatory cytokines. Figure 3 shows that the $M$. americana extract showed a significant concentration-dependent effect on all mediators with particular emphasis on the NO and IL-1 $\beta$, even to the lower concentration tested of $50 \mu \mathrm{g} / \mathrm{ml}$. M. americana is a species recognized for its high content of coumarins (Crombie et al., 1987; Yang et al., 2005). Studies of this species in terms of its health benefits are limited. Some studies have been conducted on its properties related to the use of leaves, seeds, and bark as antibacterial, anthelmintic, antiviral, and antimalarial (Gómez-Calderón et al., 2017; González-Stuart, 2011; Toma et al., 2005). Until now, there are no studies that validate the anti-inflammatory activity of Mamey (M. americana); therefore, the present work is an important contribution to the knowledge of the anti-inflammatory properties of this species.

On the other hand, A. cumanensis (seeds) extract exerts its effects even at concentrations as low as 6 and 12 $\mu \mathrm{g} / \mathrm{ml}$ in all inflammatory mediators evaluated (Fig. 3). Ambrosia cumanensis is recognized for its high content of sesquiterpene lactones, compounds widely recognized for their anti-inflammatory properties (Jimenez-Usuga et al., 2016). The sesquiterpene lactones coronopilin and damsin isolated from Ambrosia arborescens modulate the activation of the transcription factor NF- $\mathrm{BB}$, decreasing the production of IL-6, while ambrosanolide, a type of sesquiterpene lactone present in Ambrosia psilostachya, inhibits the production of NO in mouse peritoneal macrophages (Lastra et al., 2004; Svensson et al., 2018).

Considering the powerful activity shown by the $A$. cumanensis (seeds) extract on the evaluated cytokines, we decided to determine this extract's effect on the proinflammatory mediator PGE2 in macrophages RAW 264.7. Similar to the effect observed on cytokines, this extract inhibited LPS-induced PGE2 production in a concentration-dependent manner even at concentrations as low as 6 and $12 \mu \mathrm{g} / \mathrm{ml}$, with activity at $12 \mu \mathrm{g} /$ $\mathrm{ml}$ similar to that exerted by rofecoxib used as a control (Fig. 4). PGE2 is an essential homeostatic factor that plays an important role in the modulation of the inflammatory and immune response through the regulation of cytokine production, leukocyte migration, proliferation, and differentiation (Díaz-Muñoz et al., 2012; Kalinski, 2012). 


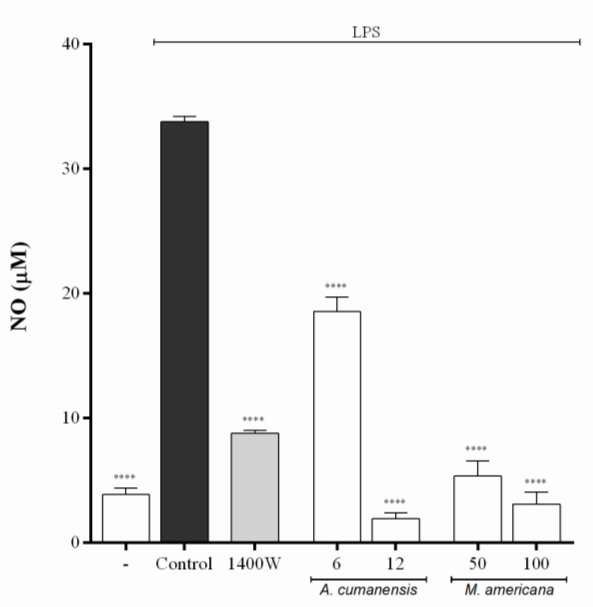

C

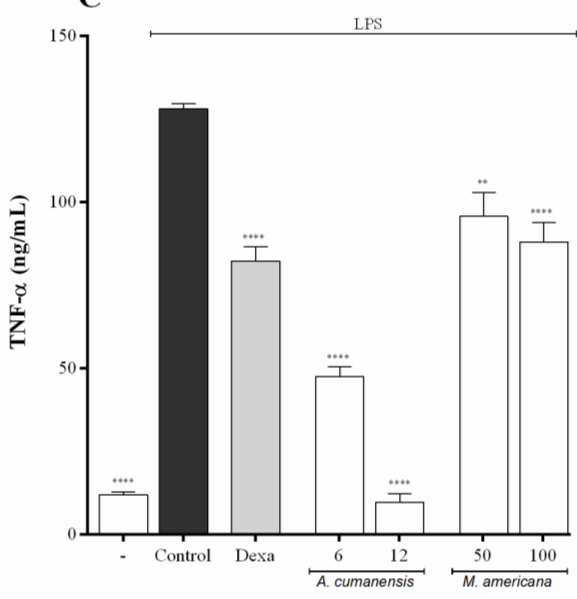

B

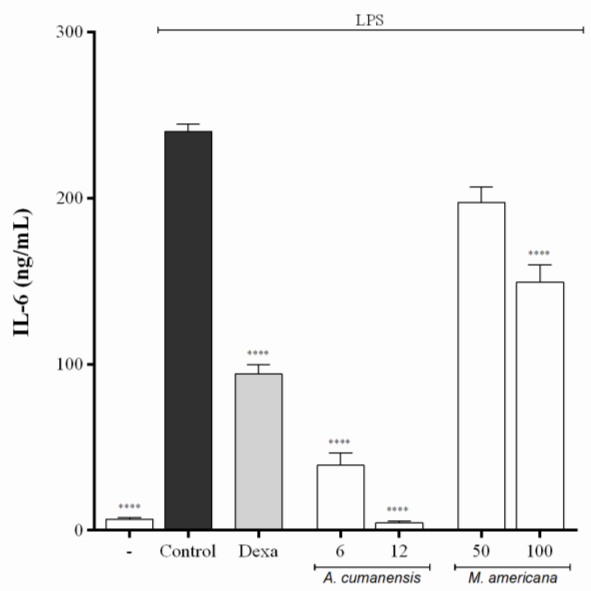

D

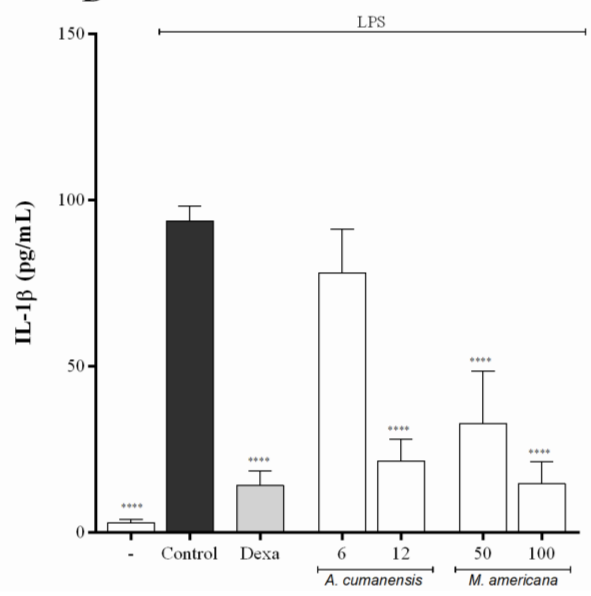

Figure 3. Effect of promissory extracts of A. cumanensis (seeds) and M. americana (leaves) on the production of NO (A), IL-6 (B), TNF- $\alpha$ (C), and IL-1 $\beta$ (D) in LPSstimulated RAW 264.7 macrophages $(1 \mu \mathrm{g} / \mathrm{ml})$ for 24 hours. -: unstimulated cells. $1400 \mathrm{~W}(10 \mu \mathrm{M})$ and dexamethasone $(20 \mu \mathrm{M})$ were used as a positive control. Results represent the mean $\pm \operatorname{SEM}\left({ }^{*} p<0.05 ; * * p<0.01 ;{ }^{* *} p<0.001 ; * * * * p<0.0001\right.$ ANOVA statistically significant compared with LPS-treated group).

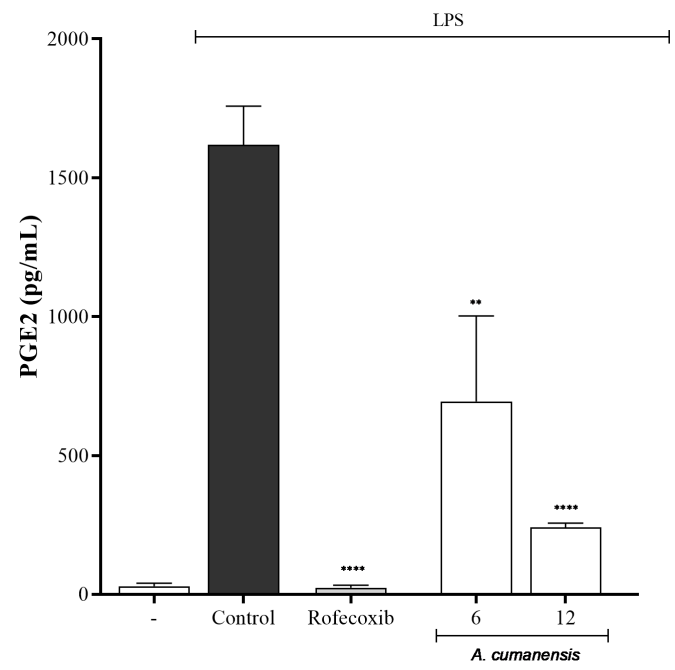

Figure 4. Effect of promissory extracts of A. cumanensis (seeds) on the production of PGE2 in LPS-stimulated RAW 264.7 macrophages $(1 \mu \mathrm{g} / \mathrm{ml})$ for 24 hours. -: unstimulated cells. Rofecoxib $(10 \mu \mathrm{M})$ was used as positive control. Results represent the mean \pm SEM $(* * p<0.01 ; * * * * p<0.0001$ ANOVA statistically significant compared with LPS-treated group).

\section{CONCLUSION}

Our results show the anti-inflammatory potential of 15 extracts of 13 plant species of the Colombian Caribbean coast, which significantly inhibit the production of the NO inflammatory mediator. Extracts of the species A. cumanensis and $M$. americana are the most promising, inhibiting the production of all evaluated inflammatory mediators significantly, constituting a valuable biological resource of the Colombian diversity on which bioprospecting must be applied to develop new therapeutic alternatives for the treatment of diseases that occur with inflammatory processes.

\section{ACKNOWLEDGMENTS}

The authors thank the Universidad de Cartagena, Colombia, for financial support (091-2017, 027-2018, 095-2018, and 099-2018). Jenny Castro is deeply grateful to Colciencias and the Universidad de Cartagena for their doctoral scholarship through the National Doctoral Training Program (647-2014). The authors thank Deimer Torrado, Alexandra Cedeño, and Monica Mallarino for their assistance in the in vitro anti-inflammatory activity assays. 


\section{AUTHOR CONTRIBUTIONS}

FD and LF conceived the study; FD, LF, and JC supervised the study, designed experiments, and carried out the experiments; JC, LF, and FD wrote the manuscript. All authors read and approved the final manuscript.

\section{CONFLICTS OF INTEREST}

The authors report no financial or any other conflicts of interest in this work.

\section{ETHICAL APPROVALS}

Not applicable.

\section{PUBLISHER'S NOTE}

This journal remains neutral with regard to jurisdictional claims in published institutional affiliation.

\section{REFERENCES}

Animesh B, Bari M, Mohashweta R, Bhadra S. Inherited folk pharmaceutical knowledge of tribal people in the Chittagong Hill tracts, Bangladesh. Indian J Tradit Knowl, 2010; 9(1):77-89.

Beyra Á, León M, Iglesias E, Ferrándiz D, Herrera R, Volpato G, Godínez D, Guimarais M, Álvarez R. Estudios etnobotánicos sobre plantas medicinales en la provincia de Camagüey (Cuba). An Jardín Botánico Madr, 2004; 61(2):185-204.

Bogdan C. Nitric oxide synthase in innate and adaptive immunity: an update. Trends Immunol, 2015; 36(3):161-78.

Brand-Williams W, Cuvelier ME, Berset C. Use of a free radical method to evaluate antioxidant activity. LWT-Food Sci Technol, 1995; 28(1):25-30.

Calder PC. Marine omega-3 fatty acids and inflammatory processes: effects, mechanisms and clinical relevance. Biochim Biophys Acta MolCell Biol Lipids, 2015; 1851(4):469-84.

Castro J, Rivera D, Franco LA. Topical anti-inflammatory activity in TPA-induced mouse ear edema model and in vitro antibacterial properties of Cordia alba flowers. J Pharm Investig, 2019; 49(3):331-6.

Conforti F, Menichini F. Phenolic compounds from plants as nitric oxide production inhibitors. Curr Med Chem, 2011; 18(8):1137-45.

Crombie L, Jones RC, Palmer CJ. Synthesis of the Mammea coumarins. Part 1 . The coumarins of the mammea A, B, and C series. J Chem Soc Perkin Trans 1, 1987; 317-31.

De Vega JJ, Davey RP, Duitama J, Escobar D, Cristancho-Ardila MA, Etherington GJ, Minotto A, Arenas-Suarez NE, Pineda-Cardenas JD, Correa-Alvarez J. Colombia's cyberinfrastructure for biodiversity: building data infrastructure in emerging countries to foster socioeconomic growth. Plants, People, Planet, 2020; 2(3):229-36.

Del-Toro-Sánchez CL, Bautista-Bautista N, Blasco-Cabal JL, Gonzalez-Ávila M, Gutiérrez-Lomelí M, Arriaga-Alba M. Antimutagenicity of methanolic extracts from Anemopsis californica in relation to their antioxidant activity. Evid Based Complement Alternat Med, 2014; 2014:273878

Díaz-Muñoz MD, Osma-García IC, Fresno M, Iñiguez MA. Involvement of PGE2 and the cAMP signalling pathway in the up-regulation of COX-2 and mPGES-1 expression in LPS-activated macrophages. Biochem J, 2012; 443(2):451-61.

Duarte O, Velho L. Análisis del marco legal en Colombia para la implementación de prácticas de bioprospección. Acta Biol Colomb, 2008; 13(2):103-22.

Fernandez-Panchon M, Villano D, Troncoso A, Garcia-Parrilla M. Antioxidant activity of phenolic compounds: from in vitro results to in vivo evidence. Crit Rev Food Sci Nutr, 2008; 48(7):649-71.

Ferrari M, Fornasiero MC, Isetta AM. MTT colorimetric assay for testing macrophage cytotoxic activity in vitro. J Immunol Methods, 1990; 131(2):165-72.
Gailea R, Bratawinata AA, Pitopang R, Kusuma I. The use of various plant types as medicines by local community in the enclave of the Lore-Lindu national park of Central Sulawesi, Indonesia. Glob J Res Med Plants Indig Med, 2016; 5(1):29.

Germosén L, García M, Morón F, Costaguta M, Delens M, Olmedo D, Méndez M, Boulogne I, García R, Durán R. Farmacopea vegetal caribeña. Universidad de Cartagena, Cartagena, Colombia, 2017.

Girón N, Pérez-Sacau E, López-Fontal R, Amaro-Luis JM, Hortelano S, Estevez-Braun A, de las Heras B. Evaluation of labdane derivatives as potential anti-inflammatory agents. Eur J Med Chem, 2010; 45(7):3155-61.

Gómez-Calderón C, Mesa-Castro C, Robledo S, Gómez S, Bolivar-Avila S, Diaz-Castillo F, Martínez-Gutierrez M. Antiviral effect of compounds derived from the seeds of Mammea americana and Tabernaemontana cymosa on dengue and chikungunya virus infections. BMC Complement Altern Med, 2017; 17(1):57.

Gómez-Estrada H, Díaz-Castillo F, Franco-Ospina L, MercadoCamargo J, Guzmán-Ledezma J, Medina JD, Gaitán-Ibarra R. Folk medicine in the northern coast of Colombia: an overview. J Ethnobiol Ethnomed, 2011; 7(1):27.

González-Stuart A. Potential chemopreventive effects of fruits, vegetables, and spices consumed in Mexico. Nutrients, Dietary Supplements, and Nutriceuticals, Springer, Berlin, Germany, pp 287-300, 2011.

Green LC, Wagner DA, Glogowski J, Skipper PL, Wishnok JS, Tannenbaum SR. Analysis of nitrate, nitrite, and [15N] nitrate in biological fluids. Anal Biochem, 1982; 126(1):131-8.

Herrera A, Franco L, Fang L, Díaz A. Susceptibility of Porphyromonas gingivalis and Streptococcus mutans to antibacterial effect from Mammea americana. Adv Pharmacol Sci, 2014; 2014:384815.

Jimenez-Usuga N, Malafronte N, Cotugno R, De Leo M, Osorio E, De Tommasi N. New sesquiterpene lactones from Ambrosia cumanensis Kunth. Fitoterapia, 2016; 113:170-4.

Kalinski P. Regulation of immune responses by prostaglandin E2. J Immunol, 2012; 188(1):21-8.

Killeen MJ, Linder M, Pontoniere P, Crea R. NF- $\kappa \beta$ signaling and chronic inflammatory diseases: exploring the potential of natura products to drive new therapeutic opportunities. Drug Discov Today, 2014; 19(4):373-8.

Kühl AA, Erben U, Kredel LI, Siegmund B. Diversity of intestinal macrophages in inflammatory bowel diseases. Front Immunol, $2015 ; 6: 613$.

Lastra A, Ramirez T, Salazar L, Martinez M, Trujillo-Ferrara J. The ambrosanolide cumanin inhibits macrophage nitric oxide synthesis: some structural considerations. J Ethnopharmacol, 2004; 95(2-3):221-7.

Lugrin J, Rosenblatt-Velin N, Parapanov R, Liaudet L. The role of oxidative stress during inflammatory processes. Biol Chem, 2014 395(2):203-30.

Manson SC, Brown RE, Cerulli A, Vidaurre CF. The cumulative burden of oral corticosteroid side effects and the economic implications of steroid use. Respir Med, 2009; 103(7):975-94.

Medzhitov R. Origin and physiological roles of inflammation. Nature, 2008; 454(7203):428-35.

$\mathrm{Na}$ YR, Je S, Seok SH. Metabolic features of macrophages in inflammatory diseases and cancer. Cancer Lett, 2018; 413:46-58.

Ospina LAF, Buendía YCO, Ibarra RG. Nitric oxide inhibitory activity of hydrogenated synthetic analogues of furanonaphthoquinones isolated from Tabebuia spp. Rev Cubana Farm, 2013; 47(4):502-16.

Re R, Pellegrini N, Proteggente A, Pannala A, Yang M, RiceEvans C. Antioxidant activity applying an improved ABTS radical cation decolorization assay. Free Radic Biol Med, 1999; 26(9-10):1231-7.

Sharma P, Patil D, Patil A. Crataeva tapia linn.-an important medicinal plant: a review of its traditional uses, phytochemistry and pharmacological properties. Int J Pharm Sci Res, 2013; 4(2):582.

Shi W, Wang Y, Cheng N, Chen B, Li D. Meta-analysis on the effect and adverse reaction on patients with osteoarthritis and rheumatoid 
arthritis treated with non-steroidal anti-inflammatory drugs. Zhonghua liu xing bing xue za zhi, 2003; 24(11):1044-8.

Sofi MS, Nabi S. The role of phytocompounds in cancer treatment: a current review. J Med Plant Stud, 2018; 6(4):83-93.

Sreejayan, Rao MN. Nitric oxide scavenging by curcuminoids. J Pharm Pharmacol, 1997; 49(1):105-7.

Svensson D, Lozano M, Almanza GR, Nilsson BO, Sterner O, Villagomez R. Sesquiterpene lactones from Ambrosia arborescens mill. inhibit pro-inflammatory cytokine expression and modulate NF- $\mathrm{kB}$ signaling in human skin cells. Phytomedicine, 2018; 50:118-26.

Toma W, Hiruma-Lima C, Guerrero R, Brito AS. Preliminary studies of Mammea americana L.(Guttiferae) bark/latex extract point to an effective antiulcer effect on gastric ulcer models in mice. Phytomedicine, 2005; 12(5):345-50.

Treuter E, Fan R, Huang Z, Jakobsson T, Venteclef N. Transcriptional repression in macrophages — basic mechanisms and alterations in metabolic inflammatory diseases. FEBS Lett, 2017; 591(19):2959-77.
Wallace JL. Nitric oxide as a regulator of inflammatory processes. Mem Inst Oswaldo Cruz, 2005; 100:5-9.

Yang H, Protiva P, Gil RR, Jiang B, Baggett S, Basile MJ, Reynertson KA, Weinstein IB, Kennelly EJ. Antioxidant and cytotoxic isoprenylated coumarins from Mammea americana. Planta Med, 2005; 71(09):852-60.

How to cite this article:

Castro JP, Franco LA, Diaz F. Anti-inflammatory screening of plant species from the Colombian Caribbean Coast. J Appl Pharm Sci, 2021; 11(04):106-117. 